\title{
FEATURES OF PUBLIC ADMINISTRATION IN THE FIELD \\ OF ROAD INFRASTRUCTURE IN UKRAINE AND TAKING INTO ACCOUNT OF EU STANDARDS FOR ITS IMPROVEMENT
}

\author{
Myroniuk R. V., Myroniuk S. A.
}

\section{INTRODUCTION}

Road transport is one of the most important branches of social production and is designed to meet the needs of the population and social production in spatial movement. The purpose of public administration in the field of road transport is timely, complete and high-quality satisfaction of these transportation needs and the needs of state defense, protection of rights during transport services, safe operation of transport, compliance with the required pace and proportions and more.

Proper functioning of road transport is not possible without the existence of a developed and high-quality road infrastructure, which despite 30 years of independence (ie creation) of our country is just beginning to develop in accordance with global, including European standards, and therefore requires both adequate funding and quality public administration. So to assess the place of highways in the national transport system, a number of factors that represent public information should be cited. Thus, the length of state roads in Ukraine is 169.5 thousand $\mathrm{km}$. The network of main routes is spread throughout the country and connects all major cities of Ukraine, as well as provides cross-border routes with neighboring countries, of which with a hard surface -165.8 thousand $\mathrm{km}$; there are still $250,000 \mathrm{~km}$ of city streets, the condition of which is the responsibility of local authorities ${ }^{1}$. It should be noted that the general network of highways in Ukraine was actually built by the end of the 80s and to this day is in a state of mostly reconstruction, with the small exception of new construction. It is obvious that today the development of public roads lags behind the pace of motorization of the country at least five times, so the number of cars compared to the 1980s today has increased 7 times, while the growth of roads has increased by 1, 5 times. During 1990-2010, their length did not increase. It should also be noted that the density of roads in Ukraine is 6.6 times lower than in France (respectively 0.28 and 1.84 kilometers of roads per 1 square kilometer of the country). The length of highways in Ukraine is 0.28 thousand kilometers (in Germany-

\footnotetext{
${ }^{1}$ Модернізаційні пріоритети реформування транспортно-дорожнього комплексу в Україні. Київ : НІСД, 2013. 32 с.
} 
12.5 thousand kilometers, in France - 7.1 thousand kilometers), and the level of funding for one kilometer of roads in Ukraine, respectively, 5.5-6 times less than in these countries. Not surprisingly, in 2017, Ukraine ranked 133rd out of 148 countries in the ranking of American researchers who asked drivers of one and a half hundred countries whether they are satisfied with their roads ${ }^{2}$. Thus, the problem of complex administration in the field of road infrastructure in Ukraine is urgent, which must be solved taking into account the international, primarily European experience of effective public management in this area, which is the subject of research within this scientific article.

Based on the subject of the study, it should be determined that public administration (management) in the field of road infrastructure includes the following components: the state of legal support for the functioning of road infrastructure in Ukraine and identify prospects for its improvement; legal grounds, procedure and conditions for financing road infrastructure in Ukraine and abroad; efficiency of the system of public administration bodies in the field of road infrastructure and identification of ways to improve it.

\section{The state of legal support for the functioning of the road infrastructure in Ukraine and the definition of prospects for its improvement}

Thus, the Constitution of Ukraine, in Article 116 of the management of state property in accordance with the law (in relation to road infrastructure) is referred to the powers of the Cabinet of Ministers of Ukraine ${ }^{3}$. The Law of Ukraine "On Motor Roads", defines the legal, economic, organizational and social principles of ensuring the functioning of roads, their construction, reconstruction, repair and maintenance in the interests of the state and road users. In particular, it defines the concepts of "highway", "street", "road surface", defines the types of roads and their components, road management authorities and their powers. The novelty of this law is the definition of the legal status of roads in Ukraine, the classification and procedure for transferring public roads to the category of toll and general principles of financing the construction, reconstruction, repair and maintenance of roads.

Concerning normative acts in the field of road infrastructure of Ukraine are the Laws of Ukraine "On Transport" and "On Road Transport", which

${ }^{2}$ Антощишина Н.I. Інтеграційні процеси транспортної системи України в СС. Ефективна економіка. 2013. № 10. URL : http://www.economy.nayka.com.ua/?op=1 $\& \mathrm{z}=2423$ (дата звернення: 05.06.2020).

${ }^{3}$ Конституція України від 28 червня 1996 р. Відомості Верховної Ради Украӥни. 1996. № 30. Ст. 141.

${ }^{4}$ Про автомобільні дороги : Закон України від 8 вересня 2005 р. № 2862-IV. Відомості Верховної Ради України. 2005. № 51. Ст. 556. 
define the legal, economic, organizational and social bases of transport (including road transport and road infrastructure), define the concept and content of the transport system of Ukraine., governing bodies in the field of road transport and road infrastructure, types of road transport, general principles of road transport safety, etc. ${ }^{5}$.

Laws that determine the sources of financing the construction, reconstruction, repair and maintenance of public roads are the Tax Code of Ukraine, the Laws of Ukraine "On sources of financing the road industry of Ukraine", "On concessions" ". Thus, the Law of Ukraine "On Sources of Financing of the Road Economy of Ukraine" defines the legal basis for financing the costs associated with the construction, reconstruction, repair and maintenance of public roads and rural roads of Ukraine.

At the by-law level, the issues of public administration of road infrastructure in Ukraine are regulated by a number of acts. Thus, the Resolution of the Cabinet of Ministers of Ukraine (hereinafter - the Cabinet of Ministers) of September 16, 2015 № 712, defines an exhaustive list of public roads of state importance ${ }^{8}$. The Resolution of the Cabinet of Ministers of December 20, 2017 № 1085 defines the mechanism for directing funds from the state road fund, which is created as part of a special fund of the state budget and calculations of budget funding for construction, reconstruction, repair and maintenance of roads in Ukraine ${ }^{9}$.

Some normative acts of the Government of Ukraine define strategic (short-term and long-term) plans for reforming the road infrastructure sector of Ukraine. In particular, in the National Transport Strategy of Ukraine for the period up to 2030, approved by the Order of the Cabinet of Ministers of May 30, 2018 № 430-r. ${ }^{10}$ provides for the development of a priority network of highways, namely: providing short-, medium- and long-term planning for

\footnotetext{
${ }^{5}$ Про автомобільний транспорт : Закон України від 5 квітня 2001 р. № 2344-III. Відомості Верховної Ради Украӥни. 2001. № 22. Ст.105.

${ }^{6}$ Про джерела фінансування дорожнього господарства України : Закон України від 18 вересня 1991 р. № 1562-ХІІ. Відомості Верховної Ради Украӥни. 1991. № 47. Ст. 648.

${ }^{7}$ Про концесію : Закон України від 3 жовтня 2019 р. № 155-IX. Відомості Верховної Ради України. 2019. № 48. Ст. 325.

8 Про затвердження переліку автомобільних доріг загального користування державного значення : Постанова КМУ від 16 вересня 2015 р. № 712 . Офіиійний вісник України. 2015. № 76. С. 278. Ст. 2514.

9 Про затвердження Порядку спрямування коштів державного дорожнього фонду : Постанова Кабінету Міністрів України від 20 грудня 2017 р. № 1085. Офічійний вісник Украӥни. 2018. № 6. С. 138. Ст. 249.

${ }_{10}$ Про схвалення Національної транспортної стратегії України на період до 2030 року : Розпорядження КМУ від 30 травня 2018 р. № 430-р. Офіційний вісник Украӥни. 2018. № 52. С. 533. Ст. 1848.
} 
the development of highways; identification of key indicators of road management efficiency and monitoring system for their implementation; introduction of European standards of design, development and maintenance of roads, improving the quality of road surface and the validity of the choice of its type, in particular by gradually restoring the operational characteristics of the road network; improving the quality and durability of roads on the basis of design and estimate documentation and conclusions of the feasibility study; increasing the share of paved public roads; development of a network of road service points to ensure verification of compliance with the requirements of work and rest regimes of drivers in accordance with the European Agreement on the Work of Crews of Vehicles Performing International Road Transport (EUTR); introduction of long-term contracts for the maintenance of roads based on their work and final results; increasing the number of mobile dimensional and weight complexes and ensuring effective control over exceeding the dimensional and weight parameters of vehicles; creation of a competitive environment and a favorable business climate in the market of transport services, in particular, expansion of the list of services provided by enterprises of the transport industry, etc.

The order of the Cabinet of Ministers of March 28, 2018 № 231-r "On approval of the action plan to implement the Strategy for improving road safety in Ukraine until 2020» provides for a number of measures aimed at developing road infrastructure of Ukraine, in particular: arrangement of unregulated intersections protected turns, and on highways, streets, in places of turn - brake lanes; increasing the informativeness of highways and their infrastructure; equipping sections of the road network with a transport fence, in particular one that separates oncoming traffic directions; application of the newest technical means of the organization of road traffic with the improved characteristics of perception by participants of movement and the raised characteristics of wear resistance (a marking, lighting); modernization of traffic light facilities; ensuring the safety of roadsides, their strengthening and cleaning; construction of ring intersections of small radius, etc.; bringing the requirements for the placement of outdoor advertising on international highways in line with the European Agreement on International Motorways; strengthening road safety at railway crossings and approaches to them; lighting of streets and roads with the use of energy-saving technologies, especially on sections of category I roads passing through settlements.

The Strategic Plan for the Development of Road Transport and Roads for the period up to 2020, developed by Ukravtodor and approved by the Resolution of the Cabinet of Ministers of December 21, 2015 provides for the achievement of the following key goals: modernization of the existing road management system; reconstruction and / or technical maintenance of the road network; effective management of the use of the car network; 
improving the quality and safety of services for the carriage of passengers and goods, etc. ${ }^{11}$.

It should also be noted that the share of international legal acts that regulate the relations of public administration of road infrastructure in Ukraine are agreements to attract foreign investment in this area. In particular, it should be noted that on July 9, 2018 between Ukraine and the European Investment Bank signed a Financing Agreement for the Project "Improving road safety in the cities of Ukraine" ${ }^{12}$. According to this project, the Ministry of Infrastructure has been appointed the responsible executor of the Project, which is provided by the order of the Ministry of Finance dated 03.07.2018 № 596 “On the expediency of preparing a joint reconstruction with the European Investment Bank. The estimated cost of the Project (according to EIB experts) is EUR 177 million (excluding VAT), of which loans: EIB - EUR 75 million; EBRD - 75 million euros; the rest - own funds of cities, technical assistance. The main task of the Project is to reduce the number of fatalities and serious injuries in road accidents in urban areas, with special attention to the two categories of victims - pedestrians and cyclists, improving urban road infrastructure to reduce road accidents; improving the infrastructure of road intersections; street renovations: improving infrastructure for pedestrians, cyclists and public transport and utilities; preparation of itinerary action plans or programs of wide zones (speed reduction in settlements or near schools); support for the legal and monitoring framework for the implementation of such measures. The Project is planned to be implemented in the following cities: Lviv, Odesa, Dnipro, Kharkiv, Kyiv and Kamyanets-Podilsky.

Given the analysis of regulations that in one way or another regulate the principles of public administration in the field of road infrastructure and based on strategic development plans in this area in Ukraine, it is advisable to make the following legislative changes: adopt the Law "On Road Infrastructure" to define legal, economic, organizational and social principles of ensuring the functioning of road infrastructure, directions of its development, reconstruction, repair and maintenance with definition of clear jurisdiction of specific public authorities responsible for its maintenance and financing, or supplement the Law of Ukraine "On Road Traffic" with a

${ }^{11}$ Про затвердження Стратегічного плану розвитку автомобільного транспорту та дорожнього господарства на період до 2020 року : Наказ Міністерства інфраструктури України від 21 грудня 2015 р. № 548. Сайт Мініфраструктури. URL : https://mtu.gov.ua/projects/26 (дата звернення: 05.06.2020).

12 Про ратифікацію Фінансової угоди (Проєкт «Підвищення безпеки автомобільних доріг в містах України») між Україною та Європейським інвестиційним банком : Закон України від 19 грудня 2019 р. № 415-IX. Офіційний вісник Украӥни. 2020. № 3. С. 35. Ст. 123. 
separate section such legal bases; to adopt the Resolution of the Cabinet of Ministers of Ukraine "On the procedure for maintenance of roads and road infrastructure of Ukraine", which determines on the basis of the Law "On Roads" types of roads and their infrastructure, and determine the jurisdiction of each public authority for their maintenance, including jurisdiction: Ukravtodor, road services of local authorities, local governments.

\section{Legal bases, order and conditions of financing of road infrastructure in Ukraine}

At present, the main source of funding for the development of the network of public roads is the funds of the state and local budgets (Table 1). The state budget finances the repair and maintenance of long-distance roads, and local budgets are responsible for similar work in cities and towns.

Below are key indicators of planning and spending of public funds to finance the development of road infrastructure.

Table 1

Financing of the road industry of Ukraine from the state and local budgets in 2017-2019, UAH million ${ }^{13}$

\begin{tabular}{|c|c|c|}
\hline Budget year & $\begin{array}{c}\text { Amounts (billion UAH) } \\
\text { spent from the state } \\
\text { budget }\end{array}$ & $\begin{array}{c}\text { Amounts (billion UAH) } \\
\text { spent from local budgets }\end{array}$ \\
\hline 2017 & 26,2 & 2,1 \\
\hline 2018 & 29,3 & 3,3 \\
\hline 2019 & 44,2 & 6,2 \\
\hline
\end{tabular}

As can be seen from table. 1, the financing of the road sector in Ukraine from the state budget since 2017 has been increasing proportionally annually by more than $30 \%$, while the increase in funding from local budgets has been insignificant. According to Ukravtodor, economic losses due to the unsatisfactory condition of roads reach UAH 55,000 million per year, ie about $3.7 \%$ of GDP. At the same time, the state budget provided for the repair and development of road infrastructure by 2019 a little more than $1 \%$ of GDP.

However, the planned budget funding for this area in 2020 reached the highest figure of UAH 69.7 billion, of which only UAH 4.7 billion. it is

13 Звіт Державного агентства автомобільних доріг України про виконання державного бюджету україни за 2017-2019 роки: Офіційний сайт «Укравтодору». URL : https://ukravtodor.gov.ua/4489/zvity/zvit_derzhavnoho_ahentstva_avtomobilnykh_ dorih_ukrainy_pro_vykonannia_derzhavnoho_biudzhetu_ukrainy_za_2016_rik.html (дата звернення: 05.06.2020). 
planned to attract funds from international donors, which is $38 \%$ more than in 2019.

In addition, the Cabinet of Ministers approved amendments to the State Targeted Economic Program for the Development of Public Roads of State Importance for 2018-2022, according to which the projected amount of funding for this program is 322.15 billion hryvnias, including from the state road fund - in the amount of 193.15 billion hryvnias, of which 32.76 billion hryvnias are provided for repayment of loan liabilities, 7.96 billion hryvnias at the expense of the general fund of the state budget, 20.26 billion hryvnias at the expense of international financial organizations, at the expense of investors' funds - UAH 100.78 billion.

All this indicates that today we are reaching economically sound indicators of financing the development of road infrastructure in Ukraine, which will bring this area closer to European standards and increase the level of investment attractiveness of Ukraine, which will boost the country's economy.

Below it is expedient to give economic and legal means of formation of financing of road infrastructure in Ukraine. For the purposes of financing works related to the construction, reconstruction, repair and maintenance of public roads, a state road fund is created within the special fund of the State Budget of Ukraine. The income part of this fund is formed at the expense of: 1) excise tax on fuel and vehicles produced in Ukraine; 2) excise tax on fuel and vehicles imported into the customs territory of Ukraine; 3) import duty on petroleum products and vehicles and tires for them; 4) tolls for motor vehicles and other self-propelled machines and mechanisms, the weight or dimensions of which exceed the normative; 5) funds of the special fund of the State Budget of Ukraine, obtained by the state attracting credits (loans) from banks, foreign states and international financial organizations for the development of the network and maintenance of public roads; 6) tolls on toll public roads of state importance, the maximum amount and procedure for which are set by the Cabinet of Ministers of Ukraine; 7) concession payments - in the case of construction and operation of roads on the terms of the concession; 8) other revenues provided for by the State Budget of Ukraine, in the amounts determined by the law on the State Budget of Ukraine for the relevant year; 9) tolls for the passage of vehicles and other self-propelled machines and mechanisms, the weight or dimensions of which exceed the normative; 10) administrative and economic fines for violation of the legislation on road transport and administrative fines for offenses provided for in part one of Article 122-2 and part two of Article 132-1 of the Code of Ukraine on Administrative Offenses.

In turn, the funds of the State Road Fund of Ukraine are directed to: 
1. For financial support of construction, reconstruction, repair and maintenance of public roads of state importance, as well as the implementation of design and survey and research work, the creation and operation of information and analytical system of road management, ensuring the development of production facilities of road organizations; maintenance of branch medical establishments for rehabilitation of participants of liquidation of consequences of catastrophe at the Chernobyl nuclear power plant; conducting tenders and preparation of contracts for construction, reconstruction, repair and maintenance of public roads at the expense of international financial organizations, other creditors and investors, co-financing of these works in accordance with the relevant agreements, monitoring their implementation and commissioning of roads, road management.

The main administrator of the state road fund, which is directed to the financial support of construction, reconstruction, repair and maintenance of public roads of state importance is the central executive body that implements state policy in the field of road management - State Agency of Motor Roads of Ukraine (hereinafter - Ukravtdor).

2. A subvention from the State Budget of Ukraine to local budgets to finance the construction, reconstruction, repair and maintenance of public roads of local importance, as well as streets and roads of communal property in settlements, which is distributed among local budgets depending on the length of public roads of local importance the value of the relevant administrative-territorial unit. This subvention may be used for construction, reconstruction, repair and maintenance of streets and roads of communal property in settlements in the amount of not more than 20 percent of the amount of such subvention approved by the law on the State Budget of Ukraine for the relevant local budget.

The main administrators of these funds, which are directed to the territorial road funds, are the Council of Ministers of the Autonomous Republic of Crimea, the relevant regional, Kyiv and Sevastopol city state administrations (Local executive bodies).

3. For financial support of measures to ensure road safety in accordance with state programs.

The main administrator of the state road fund, which is used to finance road safety measures in accordance with state programs, is the central executive body that ensures the formation and implementation of state policy in the field of transport (Ministry of Infrastructure of Ukraine).

Expenditures to finance works related to the construction, reconstruction, repair and maintenance of public roads of local importance, streets and roads of communal property in settlements are provided annually in local budgets 
(ie, in the budget of the Autonomous Republic of Crimea, regional, urban, rural and village budgets for the current year).

Funds of territorial road funds are directed to the construction, reconstruction, repair and maintenance of public roads of local importance, streets and roads in settlements belonging to communal property, as well as to the needs of road management in areas determined by the Verkhovna Rada of the Autonomous Republic of Crimea, regional, city, settlement and village councils.

According to the Procedure for directing funds of the state road fund, approved by the Resolution of the Cabinet of Ministers of Ukraine of December 20, 2017 № 1085 financial support for construction, reconstruction, repair and maintenance of public roads of state importance is carried out through the following payments:

$$
\text { Д }=(\mathrm{A}+\mathrm{B}+\mathrm{C}+\mathrm{D}+\mathrm{E}) \times \frac{60}{100}-\mathrm{Z}_{\mathrm{dz}},
$$

A - excise tax on fuel and vehicles produced in Ukraine, which is credited to the special fund of the state budget in the planning year; B excise tax on fuel and vehicles imported into the customs territory of Ukraine, which is credited to the special fund of the state budget in the planning year; $\mathrm{C}$ - import duty on petroleum products and vehicles and tires to them, which is credited to the special fund of the state budget in the planning year; D - tolls for vehicles and other self-propelled machines and mechanisms, the weight or dimensions of which exceed the normative; Etoll for toll public roads of state importance; $\mathrm{Zdz}$ - the amount of payments required in the relevant year for the fulfillment of debt obligations on borrowings received by the state or under state guarantees for the development of the network and maintenance of public roads.

The amount of budget funds for the financial support of construction, reconstruction, repair and maintenance of public roads of local importance, streets and roads of communal property in settlements, including the arrangement of parking spaces, stops, parking of vehicles is calculated as a subvention from the state budget to local budgets (hereinafter - the subvention) between the budget of the Autonomous Republic of Crimea, regional budgets and budgets of $\mathrm{mm}$. Kyiv and Sevastopol, depending on the length of public roads of local importance in the relevant administrativeterritorial unit as of January 1 of the year preceding the planned, with at least 80 percent spent on construction, reconstruction, repair and maintenance of public roads of local importance, and not more than 20 percent - for the construction, reconstruction, repair and maintenance of streets and roads of communal property in settlements. 
Thus, the peculiarity of financing road infrastructure in Ukraine is as follows:

1) expenditures on financing works related to construction, reconstruction, repair and maintenance of public roads are carried out at the expense of the state road fund, as a component of the State Budget of Ukraine, formed by the Cabinet of Ministers of Ukraine (Government), adopted by the Verkhovna Rada of Ukraine. Parliament of the country), signed by the President of Ukraine (head of state) in December of the current budget year;

2) expenditures on financing works related to construction, reconstruction, repair and maintenance of public roads of local significance, as well as streets and roads of communal property in settlements are carried out at the expense of territorial (local) road funds as a component of city budgets, villages, settlements and united territorial communities, which are formed and adopted by local councils (regions, cities, villages, settlements) and signed by their chairmen.

This distribution of financing of road infrastructure of Ukraine is logical because public roads are state property, and therefore their financing is carried out from the state budget, and public administration is carried out by public authorities in the manner prescribed by the Government of Ukraine; accordingly, local roads (ie those used mainly by residents of relevant cities, villages, settlements) are municipal property, and therefore their funding is provided mainly from local budgets, and public administration is carried out by local authorities in the manner prescribed by the relevant councils.

However, the main problem of proper administration of road infrastructure in Ukraine, and consequently funding for construction, reconstruction and maintenance of roads is primarily the lack of a national classifier of roads in Ukraine (road map of road ownership), which would contain a complete classification of roads by dividing them. the following categories: 1) public roads of state importance; 2) public roads of local significance; 3) highways of settlements; 4) private roads; 5) highways of state enterprises of closed type, on the territory of which the internal movement of transport is carried out.

It should be noted that the first two categories of public roads of state and local significance acquired their normative definition in the Law of Ukraine “On Motor Roads” of September 8, 2005 № 2862-IV, but this did not solve the problem of their proper public administration. At the legislative level, only general features of classifying highways to a certain category are defined, without their classification and delimitation of areas of jurisdiction (powers of a certain subject of public administration) for construction, reconstruction and maintenance, which is one of the significant shortcomings of Ukraine. European integration, investment and tourist 
attractiveness, proper use of the country's transit capacity, improving the living standards of its citizens.

\section{The system of public administration bodies in the field of road infrastructure in Ukraine}

The central executive body in this area is the Ministry of Infrastructure of Ukraine (Ministry of Infrastructure of Ukraine). The Ministry of Infrastructure of Ukraine operates on the basis of the Regulation approved by the Resolution of the Cabinet of Ministers of Ukraine of June 30, 2015 № $460^{14}$.

The main tasks of the Ministry of Infrastructure of Ukraine in the field of transport are: formation and implementation of state policy in the field of transport, use of roads; formation and implementation of state policy in the field of traffic safety.

The State Administration of Motor Roads of Ukraine and the State Inspectorate for Land Transport Safety are among the public administration bodies with authority over the functioning of road infrastructure. The State Agency of Motor Roads of Ukraine (hereinafter - Ukravtodor) is the central executive body, which operates on the basis of the Regulation approved by the Decree of the President of Ukraine of April 13, 2011 № 456/2011. The main tasks of Ukravtodor are: implementation of state policy, as well as making proposals for its formation in the field of road management; management of public roads; informing and providing explanations on the implementation of state policy in the relevant field; organization of reconstruction, repair and maintenance of highways, appropriate engineering equipment, placement of road service facilities and other structures; providing technical regulation in the field of reconstruction and overhaul of roads; management of state property; exercise of other powers determined by the laws of Ukraine and assigned to him by the President of Ukraine.

The State Inspectorate of Ukraine for Land Transport Safety (hereinafter - Ukrtransinspektsiya) is the central executive body that in the field of road transport ensures the implementation of state policy on safety in public transport, for the transportation of which issued a license and operation of public roads ${ }^{15}$. Ukrtransinspektsiya in the field of road transport performs the following functions: approves the network of international and

14 Про затвердження Положення про Державне агентство автомобільних доріг України : Постанова Кабінету Міністрів Українивід 10 вересня 2014 р. № 439. Офіційний вісник України. 2014. № 75. Т. 3. С. 2327. Ст. 2128.

15 Міжнародний круглий стіл 2016 «Міжнародні норми та стандарти у сфері безпеки на транспорті: проблематика та передова практика» 15 листопада 2016 р., м. Київ. Спікер: заступник міністра інфраструктури України Лавренюк Юрій Федорович URL : https://mtu.gov.ua/files/1.\%20LAVRENUK.pdf. 
intercity and suburban public bus routes that extend beyond the territory of the region (interregional routes), and maintains a register of such routes; issues permits for international transportation of passengers and goods; carries out the state control and supervision over observance of requirements of regulatory legal acts concerning maintenance of safety on motor transport; issues certificates on the establishment of the bus class according to the parameters of comfort; issues certificates on attestation of bus stations and maintains a list of certified bus stations; carries out dispatching control over the work of road carriers that carry passengers on interregional public routes; issues license cards for vehicles of the business entity; carries out dimensional and weight control of vehicles at checkpoints across the state border and on public roads, etc.

4. Directions for improving public administration in the field of road infrastructure in Ukraine, taking into account the experience of the EU.

In 2018, the Ministry of Infrastructure of Ukraine developed a mechanism for implementing the project "Safe and high-quality roads", which provides, first, the introduction of safety audits for long-distance roads by creating an independent safety audit and quality control of public roads, banning advertising media within the right-of-way roads, proper information of road users; secondly, the introduction of a new model of road infrastructure financing by reforming and filling the State Road Fund; timely and high-quality repair of roads by giving preference not to pit repairs of a significant part of the road, but to overhauls by gradually laying a new pavement.

Additional measures to improve public administration in the field of road infrastructure in Ukraine, taking into account the experience of the EU could be: 1) introduction of the procedure for acceptance of the rebuilt road into operation with the responsibility of the contractor who won the tender for construction, reconstruction or repair of the road. years and then for 10 years, which is fully consistent with the established world practice of road construction and maintenance; 2) determination of the responsible representative of the owner for a separate category of roads, highway, part of the road, which is possible only with the full-scale completion of the draft cadastral map of roads of Ukraine; 3 ) introduction of the procedure of public control over the expenditure of budget funds for construction, reconstruction of roads, in particular introduction of reporting to Ukravtodor, local governments, as well as contractors who won the tender for construction (repair) of the road to the public, including introduction of public audit procedure and road repairs.

Also in Ukraine, given the experience of most European countries, it is necessary to introduce the practice of building highways on the basis of concessions during their construction and operation. Thus, in France, Italy, 
and Spain, for more than 30 years, the road sector has been financed mainly by concession investments; France has $5,830 \mathrm{~km}$ of roads built and operated on concession terms; the total length of Spanish highways built by concessionaires is about $1000 \mathrm{~km}$; the United Kingdom has adopted a program to improve the network of highways, focused on attracting private funds with the transfer of design and construction rights to private firms; Germany is expanding the practice of attracting private capital for the construction and maintenance of roads; many expressways there have already paid off during the concession, have been transferred to the state and are free; Eastern European countries (Hungary, the Czech Republic, Slovakia, Poland, Lithuania) have created a legal framework for granting concessions to foreign investors for the construction and operation of roads ${ }^{16}$.

\section{CONCLUSIONS}

To intensify this process and implement the world experience in the construction and operation of roads on the principles of public-private partnership on October 3, 2019 adopted the Law "On Concession", which defines the legal basis for the concessionaire (state) in financing the construction and operation of roads, which is confirmed by the conclusion of a special agreement. This form of public-private partnership in the construction of roads is effective in the construction of highways, which according to Ukravtodor are planned to build $7075 \mathrm{~km}$ with a total cost of about 300 billion UAH. Partial implementation of these ambitious plans is carried out within the government project "Large Construction", in particular, according to which the construction of 4 thousand $\mathrm{km}$. roads, also developed a separate draft Law of Ukraine "On highways", which is currently being agreed.

At the same time, in Ukraine the process of construction of roads on the basis of concession is not becoming widespread. In our opinion, the main deterrent for investors is the low economic efficiency of infrastructure projects and the lack of practical mechanisms for providing guarantees from the state to return investment and compliance with road conditions. Yes, to really move this inviolable stone, we mean the construction of toll roads is possible in our opinion under the following conditions: 1) approval of a long-term concession program for roads in Ukraine; 2) identification, together with international experts, of Ukraine's road corridors that require construction and for which tolls will be paid (here preference should be

16 В Україні розбудовується мережа швидкісних доріг: інформація 3 сайу Укравтодору від 30.01.2020. URL : https://ukravtodor.gov.ua/press/news/v_ukraini_ rozbudovuietsia_merezha_shvydkisnykh_dorih.html (дата звернення: 05.06.2020). 
given to international motorways that provide a transit road corridor, provided that these highways should be the shortest, with minimal distortion on the horizon and should not pass through populated areas; 3) creating appropriate conditions and guarantees for investors; 4) mandatory design and construction of alternative roads to bypass tolls, or bringing existing ones in proper condition; 5) invention of the procedure for exemption of motor vehicle owners who use toll roads from paying additional excise duty on fuel; 6) introduction of insurance contracts for road infrastructure facilities, etc.

\section{SUMMARY}

The article proposes scientifically substantiated mechanisms of complex solution of problems of public administration in the field of road infrastructure in Ukraine, which must be solved taking into account the international, first of all European experience of effective public management in this field, which is the subject of research. It was found that public administration (management) in the field of road infrastructure includes the following components: the state of legal support for the functioning of road infrastructure in Ukraine and determining the prospects for its improvement; legal grounds, procedure and conditions for financing road infrastructure in Ukraine and abroad; efficiency of the system of public administration bodies in the field of road infrastructure and identification of ways to improve it.

It is proposed to adopt the Law "On Road Infrastructure" which defines the legal, economic, organizational and social principles of ensuring the functioning of road infrastructure, areas of its development, reconstruction, repair and maintenance with a clear jurisdiction of specific public authorities responsible for its maintenance and financing. Measures to improve public administration in the field of road infrastructure in Ukraine are proposed, taking into account the experience of the EU.

\section{REFERENCES}

1. Модернізаційні пріоритети реформування транспортнодорожнього комплексу в Україні. Київ : НІСД, 2013. 32 с.

2. Антощишина Н.I. Інтеграційні процеси транспортної системи України в ЄС. Ефективна економіка. 2013. № 10. URL : http://www.economy.nayka.com.ua/?op $=1 \& \mathrm{z}=2423$ (дата звернення: 05.06.2020).

3. Конституція України від 28 червня 1996 р. Відомості Верховної Ради України. 1996. № 30. Ст. 141.

4. Про автомобільні дороги : Закон України від 8 вересня 2005 р. № 2862-IV. Відомості Верховної Ради України. 2005. № 51. Ст. 556. 
5. Про автомобільний транспорт : Закон України від 5 квітня 2001 р. № 2344-III. Відомості Верховної Ради Украӥни. 2001. № 22. Ст. 105.

6. Податковий кодекс України : Закон України від 2 грудня 2010 p. № 2755-IV. Відомості Верховної Ради Украӥни. 2011. № 13-14, № $15-16$, № 17.

7. Про джерела фінансування дорожнього господарства України : Закон України від 18 вересня 1991 р. № 1562-XII. Відомості Верховної Ради Украӥни. 1991. № 47. Ст. 648.

8. Про концесію : Закон України від 3 жовтня 2019 р. № 155-IX. Відомості Верховної Ради України. 2019. № 48. Ст. 325.

9. Про затвердження переліку автомобільних доріг загального користування державного значення : Постанова КМУ від 16 вересня 2015 р. № 712. Офіиійний вісник Украӥни. 2015. № 76. С. 278. Ст. 2514.

10. Про затвердження Порядку спрямування коштів державного дорожнього фонду : Постанова Кабінету Міністрів України від 20 грудня 2017 р. № 1085. Офіиійиний вісник України. 2018. № 6. С. 138. Ст. 249.

11. Про схвалення Національної транспортної стратегії України на період до 2030 року : Розпорядження КМУ від 30 травня 2018 р. № 430-p. Офіиійний вісник України. 2018. № 52. С. 533. Ст. 1848.

12. Про затвердження плану заходів щодо реалізації Стратегії підвищення рівня безпеки дорожнього руху в Україні на період до 2020 року : Розпорядження КМУ від 28 березня 2018 р. № 231-р. Офіиіийний вісник Украӥни. 2017. № 59. С. 115. Ст. 1808.

13. Про затвердження Стратегічного плану розвитку автомобільного транспорту та дорожнього господарства на період до 2020 року : Наказ Міністерства інфраструктури України від 21 грудня 2015 р. № 548. Сайт Мініфраструктури. URL : https://mtu.gov.ua/projects/26 (дата звернення: 05.06.2020).

14. Про ратифікацію Фінансової угоди (Проєкт «Підвищення безпеки автомобільних доріг в містах України») між Україною та Європейським інвестиційним банком : Закон України від 19 грудня 2019 р. № 415-IX. Офіційний вісник України. 2020. № 3. С. 35. Ст. 123.

15. Інфраструктурні проєкти у сфері безпеки на транспорті : Проєкт «Підвищення безпеки автомобільних доріг в містах України». URL : https://mtu.gov.ua/content/infrastrukturni-proekti-u-sferi-bezpeki-naransporti.html (дата звернення: 05.06.2020).

16. Звіт Державного агентства автомобільних доріг України про виконання державного бюджету України за 2017-2019 роки. Офіційний сайт Укравтодору. URL : https://ukravtodor.gov.ua/4489/zvity/zvit_ 
derzhavnoho_ahentstva_avtomobilnykh_dorih_ukrainy_pro_vykonannia_de rzhavnoho_biudzhetu_ukrainy_za_2016_rik.html (дата звернення: 05.06.2020).

17. Про затвердження змін, що вносяться до Державної цільової економічної програми розвитку автомобільних доріг загального користування державного значення на 2018-2022 роки : Постанова Кабінету Міністрів України від 29 січня 2020 р. № 36. Офіційний вісник Украӥни. 2020. № 14. С. 90. Ст. 552.

18. Про затвердження Положення про Міністерство інфраструктури України : Постанова Кабінету Міністрів України від 30 червня 2015 р. № 460. Офіційний вісник Украйни. 2015. № 54. С. 82. Ст. 1755.

19. Про затвердження Положення про Державне агентство автомобільних доріг України : Постанова Кабінету Міністрів Українивід 10 вересня 2014 р. № 439. Офіиійний вісник Украйни. 2014. № 75. T. 3. С. 2327. Ст. 2128.

20. Про затвердження Положення про Державну інспекцію України 3 безпеки на наземному транспорті : Постанова КМУ від 17 липня 2014 р. № 299. Офіиійний вісник Украӥни. 2014. № 63. С. 288. Ст. 1739.

21. Міжнародний круглий стіл 2016 «Міжнародні норми та стандарти у сфері безпеки на транспорті: проблематика та передова практика», м. Київ, 15 листопада 2016 р. Спікер: заступник Міністра інфраструктури України Лавренюк Юрій Федорович. URL : https://mtu.gov.ua/files/1.\%20LAVRENUK.pdf.

22. Вдовенко Ю.С. Тенденції розвитку концесійної діяльності / Польський фонд міжнародних та регіональних досліджень. 05.12.2007. URL : http://pfirs.org/?p=803\&language=uk. (дата звернення: 05.06.2020).

23. В Україні розбудовується мережа швидкісних доріг : інформація із сайту «Укравтодору» від 30.01.2020. URL : https://ukravtodor.gov.ua/ press/news/v_ukraini_rozbudovuietsia_merezha_shvydkisnykh_dorih.html (дата звернення: 05.06.2020).

24. Про концесію : Закон України від 3 жовтня 2019 р. № 155-IX. Відомості Верховної Ради. 2019. № 48. Ст. 325.

25. На 300 об'єктах розпочалися будівельні роботи - в Україні стартувало «Велике будівництво». Інформація Департаменту комунікацій Секретаріату Кабінету Міністрів України від 02 березня 2020 p. URL : https://www.kmu.gov.ua/news/na-300-obyektahrozpochalisya-budivelni-roboti-v-ukrayini-startuvalo-velike-budivnictvo (дата звернення: 05.06.2020). 


\section{Information about authors:}

Myroniuk R. V.,

Doctor of Law, Professor,

Professor of the Department of Administrative Law,

Process and Administrative Activity

Dnipropetrovsk State University of Internal Affairs

26, Gagarin ave., Dnipro, 49600, Ukraine ORCID: https://orcid.org/0000-0002-9620-5451

Myroniuk S. A.,

Candidate of Law,

Senior Lecturer of the Department of Tactical and Special Training

Dnipropetrovsk State University of Internal Affairs

26, Gagarin ave., Dnipro, 49600, Ukraine

ORCID: https://orcid.org/000-0001-6462-2173 